\title{
Primary care for recipients of allogeneic hematopoietic stem cell transplantation
}

\author{
Jill Fulcher MD, Sherrie Hertz BScPhm, Christopher Bredeson MD
}

Cite as: CMAJ 2020 November 23;192:E1538. doi: 10.1503/cmaj.200160

1 Hematopoietic stem cell transplantation offers the chance of cure for myelodysplastic syndrome, myeloproliferative neoplasms and most adult acute leukemia and relapsed lymphoma

At 3 years after hematopoietic stem cell transplant (SCT), the probability of survival is 30\%-60\%, with disease recurrence accounting for $50 \%-60 \%$ of deaths. ${ }^{1}$ Cardiovascular disease (CVD), secondary malignancy and infections are leading causes of death unrelated to the primary disease. ${ }^{1}$

2

Optimal care after transplant involves a collaboration among the

SCT centre, the primary care provider and the patient

For the first 3-6 months post-SCT, care is typically provided by the SCT centre. Thereafter, the SCT centre screens for and manages complications and patient outcomes specific to SCT. The primary care provider has a critical role in primary prevention of vaccine-preventable diseases, long-term surveillance and management of cardiometabolic risks, and screening for secondary malignancy in patients after SCT. Transplant recipients should be empowered to engage actively in their long-term health care and informed about specific health risks, and the importance of revaccination, malignancy surveillance and maintenance of a healthy lifestyle (Appendix 1, available at www.cmaj.ca/ lookup/doi/10.1503/cmaj.200160/tab-related-content).

\section{3}

Compared with the general population, SCT recipients have 4 times the risk of CVD

Given the increased risk of CVD after $\mathrm{SCT},{ }^{2}$ screening for $\mathrm{CVD}$ risk factors should begin 6 months after the procedure. Hypertension, diabetes and dyslipidemia should be managed early and intensively, in line with clinical practice guidelines for patients at high risk of CVD. Recommended targets are available in Appendix 2, at www.cmaj.ca/lookup/doi/10.1503/cmaj.200160/tab-related-content.

As a result of prior therapy, SCT recipients have up to 5 times the risk of a secondary malignancy compared with the general population Because of the substantially increased risk of secondary malignancy, ${ }^{3}$ SCT recipients require more intensive and individualized screening for malignancy, as detailed in Appendix 2.

5

Prior immunity is lost after transplant, and revaccination is

necessary from 3 months after the procedure

Neutrophil recovery is normally completed within 4 weeks of transplant. Substantial lymphocyte reconstitution and associated cellular immunity has generally occurred by 3 months. ${ }^{4}$ Primary care providers are advised to follow the vaccination timing and dosage recommendations for SCT recipients in the Public Health Agency of Canada's Canadian Immunization Guide. ${ }^{5}$

\section{References}

1. D'Souza A, Fretham C. Current uses and outcomes of hematopoietic cell transplantation (HCT): 2019 summary slides, 2019. Milwaukee (WI): Center for International Blood and Marrow Transplant Research; 2019. Available: www.cibmtr.org/ReferenceCenter/ SlidesReports/Summaryslides/pages/index.aspx (accessed 2020 Nov 3).

2. Chow EJ, Baker KS, Lee SJ, et al. Influence of conventional cardiovascular risk factors and lifestyle characteristics on cardiovascular disease after hematopoietic cell transplantation. J Clin Oncol 2014;32:191-8.

3. Michelis FV, Kotchetkov R, Grunwald RM, et al. Longterm incidence of secondary malignancies after allogeneic hematopoietic cell transplantation: a singlecenter experience. Biol Blood Marrow Transplant 2017; 23:945-51.

4. Tomblyn $\mathrm{M}$, Chiller $\mathrm{T}$, Einsele $\mathrm{H}$, et al. Guidelines for preventing infectious complications among hematopoietic cell transplantation recipients: a global perspective [published erratum in Biol Blood Marrow Transplant 2010;16:294]. Biol Blood Marrow Transplant 2009;15:1143-238

5. Canadian Immunization Guide: immunization of immunocompromised persons. Ottawa: Public Health Agency of Canada; modified 2019 Nov. 1. Available: www.canada.ca/en/public-health/services/publications/ healthy-living/canadian-immunization-guide-part-3 -vaccination-specific-populations/page-8-immunization -immunocompromised-persons.html\#t3 (accessed 2020 May 28).

Competing interests: None declared.

This article has been peer reviewed.

Affiliations: Ottawa Hospital Research Institute, Department of Medicine (Fulcher, Bredeson), University of Ottawa, Ottawa, Ont.; Clinical Programs and Quality Initiatives (Hertz), Cancer Care Ontario, Toronto, Ont.

Correspondence to: Jill Fulcher, jfulcher@toh.ca 